\title{
ANÁLISE CRÍTICA DO REEXAME NECESSÁRIO À LUZ DO ACESSO À JUSTIÇA E DA RAZOÁVEL DURAÇÃO DO PROCESSO
}

\author{
THE MANDATORY APPEAL IN LIGHT OF THE CONSTITUTIONAL PRINCIPLES \\ OF ACCESS TO JUSTICE AND REASONABLE DURATION OF PROCESS
}

\author{
Rafael de Souza Borelli; Marcos Antônio Striquer Soares
}

\begin{abstract}
Sumário: Introdução. 1 Apontamentos Temático-Metodológicos . 2 Fazenda Pública E Sua Atuação Processual. 2.1 A Fazenda Pública Em Juízo E Suas Prerrogativas Processuais. 2.2 Reexame Necessário. 3 Os Direitos Fundamentais Ao Acesso À Justiça E À Razoável Duração Do Processo. 3.1 Acesso À Justiça. 3.2 Obstáculos Ao Acesso À Justiça. 3.2.1 Morosidade Processual. 3.2.2 As Possibilidades Das Partes. 3.3 Constitucionalização Do Direito À Razoável Duração Do Processo Como Solução Para O Problema Da Demora Na Prestação Jurisdicional. 4 O Reexame Necessário À Luz Do Acesso À Justiça E Da Razoável Duração Do Processo. Conclusão. Referências
\end{abstract}

\begin{abstract}
Resumo: O tratamento diferenciado concedido à Fazenda Pública vem sendo alvo de intensos debates doutrinários no seio do direito processual. O duplo grau de jurisdição obrigatório (reexame necessário), a impossibilidade de concessão de liminares, o prazo diferenciado, entre outros, são os institutos mais criticados. Neste diapasão, é importante uma leitura destes institutos (especialmente do reexame necessário) à luz do acesso à justiça e da razoável duração do processo. Como apontam Cappelletti e Garth, mais até do que os procedimentos processuais, as possibilidades de acesso à justiça (por parte dos cidadãos) vêm sendo modificadas e ampliadas desde o último quarto do século XX. Seguindo esta visão, percebe-se que, atualmente, a concessão de tratamento diferenciado ao Poder Público vem causando mais prejuízos que vantagens ao direito de acesso à justiça dos cidadãos. Inserto na temática do acesso à justiça erige-se como direito fundamental o direito à razoável duração do processo, o qual ingressou em nossa ordem constitucional através da Emenda Constitucional 45/2004. Este princípio determina que, dentro das possibilidades fáticas e jurídicas do caso concreto, as demandas judiciais sejam solucionadas em um prazo razoável, possibilitando que o objeto do litígio não se torne inútil às partes. Prosseguindo, à luz tanto do acesso à justiça como da razoável duração do processo será realizada apreciação crítica do reexame necessário (duplo grau de jurisdição obrigatório), utilizando-se como substrato teórico a obra de Celso Antônio Bandeira de Mello e Virgílio Afonso da Silva.
\end{abstract}

Palavras-chave: Fazenda Pública. reexame necessário. acesso à justiça. razoável duração do processo.

Abstract: The special treatment that the Treasury receives from procedural Law has been the target of intense doctrinal debates. The double degree of jurisdiction (mandatory appeal), the prohibition of injunction, the extended deadlines, among other things, are the most criticized institutes. In this light, these aforementioned institutes must be studied with regards to the rights of access to justice and reasonable duration of process. As pointed by Cappelletti and Garth, the means of access to justice have been modified and increased ever since the last quarter of the twentieth century. According to this view, the special treatments given to the Treasury are shown as more detrimental than helpful. Proceeding in the study, the right to a process with reasonable duration orders that among the factual and juridical possibilities of the case in study, the judicial processes be solved in a reasonable and timely fashion, allowing that the object of litigation doesn't become useless. At last, the mandatory appeal will be analyzed critically, using as foundation the studies of Celso Antônio Bandeira de Mello e Virgilio Afonso da Silva.

Keywords: Treasury. mandatory appeal. access to justice. reasonable duration of process.

\section{INTRODUÇÃO}

O presente trabalho buscará, de maneira não exauriente, estudar três institutos jurídico-processuais: o acesso à justiça, a razoável duração do processo e o reexame necessário.

Para realizar o referido exame, estruturou-se a pesquisa de forma simples. Iniciar-se-á o estudo com breve análise acerca do que seja acesso à justiça e quais são as implicações desta norma jurídica jusfundamental. Em seguida, anotar-se-ão alguns obstáculos existentes ao acesso à justiça. Como apontado anteriormente, para que seja possível o aprofundamento a ser realizado posteriormente é necessário o estudo do direito fundamental à razoável duração do processo, inserido na Constituição da

"Rafael de Souza Borellli é Bacharel em Direito pela Universidade Estadual de Londrina - UEL/PR, mestrando em Direito Negocial pela mesma instituição e procurador da Câmara Municipal de Guarulhos. Marcos Antônio Striquer Soares é Mestre e Doutor em Direito do Estado pela Pontifícia Universidade Católica de São Paulo - PUC/SP. Professor permanente do Programa de Mestrado em Direito Negocial da Universidade Estadual de Londrona 
República pela Emenda Constitucional 45/2004. Este direito à razoável duração do processo vem trazendo inúmeras implicações no meio jurídico, como as Metas de Nivelamento do Conselho Nacional de Justiça, a informatização do processo judicial, entre outras.

Adentrando-se o cerne do ensaio, serão estudadas algumas das prerrogativas processuais concedidas à Fazenda Pública, especialmente o reexame necessário, à luz dos direitos fundamentais de acesso à justiça e da razoável duração do processo. Neste sentido, o ensaio acometerá a questão da constitucionalidade e a validade do reexame, tendo em vista os princípios constitucionais da igualdade material, do acesso à justiça e da garantia constitucional da razoável duração do processo, sopesando-os sem deixar de vista a proporcionalidade.

Neste sentido, justifica-se a pesquisa ora apresentada por se tratar de tema relativamente novo no seio da literatura jurídica brasileira, sendo de maior importância ainda por realizar tentativa de sistematização dos institutos apresentados, com o fim de fomentar discussões e debates na academia.

\section{APONTAMENTOS TEMÁTICO-METODOLÓGICOS}

Por tratar-se de tão interessante e extenso tema, é necessária uma delimitação do que se irá abordar no presente artigo. Como exposto acima, a pesquisa buscará, de maneira sumária, situar a expressão "Fazenda Pública" no arcabouço jurídico pátrio, apontando alguns dos tratamentos diferenciados concedidos a ela pela lei processual (prerrogativas processuais). De maneira mais detida será analisado o reexame necessário, o qual é considerado uma das prerrogativas processuais da Fazenda Pública. A par disso, é importante ressaltar que após a conceituação de Fazenda Pública, este termo será utilizado de maneira sinônima com o termo "Poder Público".

Ademais, serão utilizadas como substrato teórico ao final do exame as teorias de Celso Antônio Bandeira de Mello e Virgílio Afonso da Silva. Apesar dos dois juristas terem visões diferenciadas do que é princípio jurídico (e este estudo perpassa por um exame principiológico) entende-se que não há sincretismo metodológico ${ }^{i}$ na utilização das teorias destes autores.

Por fim, toda a apreciação crítica será feita com base no método hipotéticodedutivo.

\section{FAZENDA PÚBLICA E SUA ATUAÇÃO PROCESSUAL}

Com o crescente aumento das funções desempenhadas pelo Estado nos dias atuais, o mesmo, naturalmente, acabou se tornando objeto de diversas relações jurídicas litigiosas, seja com seus cidadãos, seja com outros órgãos dentro de sua própria estrutura.

Prosseguindo, cabe situar a expressão Fazenda Pública, que será utilizada largamente neste ensaio. O termo é comumente usado como referência a Ministério e Secretarias da Fazenda, os quais são os órgãos estatais que controlam a gestão financeira e econômica dos entes públicos. Segundo Plácido e Silva (2005):

[...] na técnica do direito administrativo, fazenda quer dizer a soma de interesses financeiros do Estado, compreendidos por todas as suas riquezas ou bens, inclusive a gestão dos negócios que lhe são inerentes. Restritamente, significa erário, fisco ou tesouro público. 
Neste diapasão, os interesses do Estado (e consequentemente de seus cidadãos) só serão passíveis de consecução com a atuação fazendária, a qual angariará recursos para a atuação concreta do Estado na vida de seus habitantes, sendo inclusive um dos objetivos fundamentais da República Federativa do Brasil a promoção do bem de todos. Inclusive, como pontua Dallari, um dos quatro elementos necessários à formação de um Estado é o bem comum (2005, passim) ${ }^{\text {ii }}$.

Neste diapasão, nota-se que atualmente a expressão Fazenda Pública deixou de ser a apenas o sinônimo da atuação econômico-financeira estatal, passando a ser utilizada para designar as pessoas jurídicas de direito público que figurem em ações judiciais, independentemente da ação versar sobre tema fiscal ou financeiro (CUNHA, 2008, p. 15).

A Administração Pública (Fazenda Pública para os fins deste estudo) no Brasil é regida pelo Decreto-Lei 200/67 que divide-a em direta e indireta, sendo a direta formada pela União, Estados, Distrito Federal e Municípios, enquanto a indireta é formada pelas autarquias, fundações, sociedades de economia mista e empresas públicas. De posse da informação que as sociedades de economia mista e empresas públicas têm regime jurídico de direito privado (DI PIETRO, 2006, p. 414), é forçoso concluir (como acima já exposto) que a Fazenda Pública não diz respeito às denominadas empresas estatais, e sim apenas às pessoas jurídicas de direito público (União, Estados, Distrito Federal, Municípios, respectivas autarquias e fundações de direito público).

Sendo assim, para os fins deste trabalho considerar-se-á Fazenda Pública como sinônimo de pessoa jurídica de direito público.

\subsection{A FAZENDA PÚBLICA EM JUÍZO E SUAS PRERROGATIVAS PROCESSUAIS}

Seguindo a linha acima perfilhada, é notório que a Fazenda Pública recebe tratamentos diferenciados em matéria processual civil. Este tratamento é considerado por alguns como uma prerrogativa e por outros como um privilégio.

Segundo a doutrina mais tradicional a concessão dos tratamentos diferenciados à Fazenda Pública tem dupla finalidade: assegurar a igualdade substancial e a observância da supremacia do interesse público sobre o privado (VENTURI, 2010, p. 22). Para citar um autor, Nery Júnior (2004, p. 78-79) vislumbra a concessão destas diferenças de tratamento como um seguimento natural da igualdade material:

o que o princípio constitucional quer significar é a proteção da igualdade substancial, e não da igualdade meramente formal. [...] Tratar igualmente os iguais e desigualmente os desiguais é a substância do princípio da isonomia. [...] Os direitos defendidos pela Fazenda são direitos públicos, vale dizer, de toda a coletividade, sendo, portanto, metaindividuais.

Nesta trilha, Celso Antônio Bandeira de Mello (2010. p. 10) esclarece, em relação ao princípio da igualdade, que a Lei não pode servir como fonte de privilégios ou perseguições e sim como instrumento regulador da vida em sociedade, devendo tratar equitativamente todos os cidadãos, sendo este o conteúdo político-ideológico do princípio da isonomia. O mesmo autor (2004, p. 58) aponta, no que tange à concessão de prerrogativas à Fazenda Pública, que a criação das prerrogativas tem como base o princípio da supremacia do interesse público sobre o privado, o qual seria o pressuposto de uma ordem social estável. 
José Roberto de Moraes segue na mesma direção, lembrando que as prerrogativas são necessárias, vez que a Fazenda Pública atua em Juízo defendendo o Erário Público, e restando a mesma vencida na demanda, o que acabará dilapidado serão os cofres públicos, causando um prejuízo a toda a ordem social, não só à pessoa jurídica de direito público (2003, p. 69).

Por não ser o foco do presente trabalho, não será discutido aqui acerca da natureza jurídica das 'concessões' da lei processual à Fazenda Pública, se são privilégios ou prerrogativas, sendo isto feito apenas em relação ao reexame necessário.

Seguindo em frente, apontar-se-ão algumas das principais concessões que a lei processual deu à Fazenda Pública.

Uma das primeiras disposições normativas nesse sentido foi trazida pela Lei $\mathrm{n}^{\circ}$ 2.770/1956, que proibia a "concessão de medidas liminares nas ações e procedimentos judiciais de qualquer natureza" que objetivem a "liberação de bens, mercadorias ou coisas de procedência estrangeira".

Posteriormente, é de se mencionar o artigo 39 da Lei $n^{\circ} 4.357 / 1964$, que originalmente estabelecia a inviabilidade da concessão de "medida liminar em mandado de segurança, impetrado contra a Fazenda Nacional", dispondo sobre obrigações do Tesouro Nacional e Imposto de Renda. A Lei $n^{\circ} 4.862 / 1965$, todavia, revogou esta determinação, passando então a admitir a medida de urgência naquelas hipóteses, com a ressalva de que sua eficácia se estenderia pelo prazo máximo de 60 (sessenta) dias.

No ano de 1964, com a edição da Lei Federal no 4.348, que estabelecia normas processuais em mandado de segurança, foi inviabilizada a concessão de medida liminar no writ, quando impetrado "visando à reclassificação ou equiparação de servidores públicos, ou à concessão de aumento ou extensão de vantagens". De acordo com o parágrafo único do artigo $5^{\circ}$ desta lei, a segurança, nestes casos, só seria executada após o trânsito em julgado da sentença que a conceder.

Novas restrições surgiram no ano de 1966, com a Lei $\mathrm{n}^{\circ}$ 5.021. Vigente na atualidade, o diploma dispõe sobre o pagamento de vencimentos e vantagens a servidor público civil, quando assegurados em mandado de segurança. Aduz não ser possível a concessão de liminar nestes casos e pontua que tal pagamento somente "será efetuado relativamente às prestações que se vencerem a contar da data do ajuizamento da inicial.

A Medida Provisória $n^{\circ}$. 118/1989, transmutada na Lei ${ }^{\circ} 7.969$ do mesmo ano, em seu artigo $1^{\circ}$, estendeu os efeitos do ventilado artigo $5^{\circ}$ da Lei $n^{\circ} 4.348 / 64$ às medidas e ao processo de natureza cautelar.

Ulteriormente, a Lei $\mathrm{n}^{\mathrm{o}} 8.076 / 1990$, cunhada para integrar a reforma econômica implantada pelo governo da época, em seu artigo $1^{\circ}$, suspendeu, por dois anos, a concessão de liminares em ações cautelares e mandados de segurança em que fosse questionada a legislação concernente ao Plano Collor.

Nova norma proibitiva, agora em 1992, a Lei $\mathrm{n}^{\circ} 8.437$ (ainda em vigor), impediu o deferimento de medida de urgência em ações cautelares contra o Poder Público nos casos em que não fosse possível a utilização do mandado de segurança. Assim, juntando-se as leis $\mathrm{n}^{\circ}$. 8.437/1990, 5.021/1966 e 4.348/1964, vislumbra-se a ilegalidade do deferimento de liminares em favor de servidores públicos quando buscarem reclassificação ou equiparação, concessão de aumento ou extensão de vantagens.

Além das hipóteses elencadas de impossibilidade de concessão de liminares em face da Fazenda Pública, temos mais algumas prerrogativas de natureza processual.

Há previsão na Lei de Execuções Fiscais de que qualquer intimação do representante judicial da Fazenda Pública será feita pessoalmente. No âmbito federal, 
isso também acontece correntemente, por força do art. 38 da Lei Complementar 73/93 e do artigo $6^{\circ}$ da Lei 9.028/95 (MORAES, 2006, p. 71).

Outra prerrogativa é a isenção de custas, que decorre de corolário absolutamente lógico, pelo menos no que tange à União e aos Estados, uma vez que seria descabido à União pagar custas na Justiça Federal e, igualmente, aos Estados recolherem custas no seu próprio âmbito. Sendo assim, natural foi que fosse deferida isenção também ao Município.

Entre outras, estas são algumas das inúmeras prerrogativas processuais concedidas aos entes públicos quando em juízo. A prerrogativa que será mais exaurida no presente ensaio é o instituto do reexame necessário, vista abaixo.

\subsection{REEXAME NECESSÁRIO}

A remessa necessária (reexame necessário) é mais antiga que o próprio Brasil como o conhecemos hoje. Sua origem data das Ordenações Afonsinas de 1355, que previam apelação ex officio em casos de crimes cuja apuração iniciara-se por devassa, ou acaso se tratasse de delito público (ASSIS, 2008, p. 865). Nas Ordenações Manuelinas e nas Filipinas, houve aumento do alcance do instituto. Porém, até aquele tempo o reexame era típico do direito criminal, sendo instituído para fins processuais civis apenas em 1831, das decisões proferidas contra a Fazenda Pública. A partir daí o instituto tornou-se corrente no processo civil brasileiro, sendo parte das Constituições de 1934, 1937, até ser incluído no Código de Processo Civil de 1939 e posteriormente no atual Diploma Processual Civil. (ASSIS, 2008, p. 865).

$\mathrm{Na}$ legislação processual civil atual o reexame tem a seguinte redação:

Art. 475. Está sujeita ao duplo grau de jurisdição, não produzindo efeito senão depois de confirmada pelo tribunal, a sentença: (Redação dada pela Lei $\mathrm{n}^{\mathrm{o}} 10.352$, de 26.12.2001)

I - proferida contra a União, o Estado, o Distrito Federal, o Município, e as respectivas autarquias e fundações de direito público; (Redação dada pela Lei $\mathrm{n}^{\mathrm{o}}$ 10.352, de 26.12.2001).

II - que julgar procedentes, no todo ou em parte, os embargos à execução de dívida ativa da Fazenda Pública (art. 585, VI). (Redação dada pela Lei $\mathrm{n}^{\circ}$ 10.352, de 26.12.2001)

$\S 1^{\mathrm{o}}$ Nos casos previstos neste artigo, o juiz ordenará a remessa dos autos ao tribunal, haja ou não apelação; não o fazendo, deverá o presidente do tribunal avocá-los. (Incluído pela Lei $n^{\circ} 10.352$, de 26.12.2001)

$\S 2^{\circ}$ Não se aplica o disposto neste artigo sempre que a condenação, ou o direito controvertido, for de valor certo não excedente a 60 (sessenta) salários mínimos, bem como no caso de procedência dos embargos do devedor na execução de dívida ativa do mesmo valor. (Incluído pela Lei $\mathrm{n}^{\circ} 10.352$, de 26.12.2001)

$\S 3^{\circ}$ Também não se aplica o disposto neste artigo quando a sentença estiver fundada em jurisprudência do plenário do Supremo Tribunal Federal ou em súmula deste Tribunal ou do tribunal superior competente. (Incluído pela Lei $\mathrm{n}^{\mathrm{o}} 10.352$, de 26.12.2001)

Algumas leis especiais também estabelecem a obrigatoriedade do reexame obrigatório, quais sejam (rol exemplificativo):

a) as sentenças concessivas de mandado de segurança (Artigo 14 , $\S 1^{\circ}$, Lei 12.016/2009);

b) as condenações a mais do que o dobro da oferta nas desapropriações

(Decreto-lei $\mathrm{n}^{\circ} 3.365 / 41$, artigo 28 , parágrafo $1^{\circ}$ ); 
c) as sentenças que concluírem pela carência ou improcedência da ação popular (artigo 19, Lei no $4.717 / 65$ ).

Visto o diploma normativo que institui o reexame, cabe situá-lo dentro do arcabouço jurídico. Tradicionalmente existiram discussões acerca do ingresso do reexame necessário no rol dos recursos. Atualmente resta superada tal discussão. De início, cabe a leitura do que Theodoro Júnior entende por recurso (2006, p. 628):

é o meio ou remédio impugnativo apto para provocar, dentro da relação processual ainda em curso, o reexame de decisão judicial, pela mesma autoridade judiciária, ou por outra hierarquicamente superior, visando a obter-lhe a reforma, invalidação, esclarecimento ou integração.

Sendo assim, nada mais natural que o recurso seja um remédio voluntário, dependendo de um ato volitivo da parte sucumbente (CÂMARA, 2008, p. 49). Sendo decorrente de lei, o reexame então não pode ser considerado recurso.

Cássio Scarpinella Bueno (2008, p. 412) considera-o sucedâneo recursal, assim como Araken de Assis (2008, p. 875). Sucedâneo recursal para Assis é o ato apto a impugnar decisão judicial, mas que não se encontra dentro do tópico específico dos recursos (2008, p. 857).

Em outro sentido, Alvim Wambier e Medina (2008, p. 32) entendem ser o reexame necessário uma condição legal de eficácia da sentença, uma vez que só passará a proferir efeitos após nova análise pelo segundo grau de jurisdição. Humberto Theodoro (2006, p. 612) coaduna com este entendimento. Esta solução demonstra ser a mais coerente, uma vez que o sucedâneo recursal também exige ato volitivo da parte. Estabelecido que o reexame trata-se de condição legal de eficácia de sentença, passa-se a outro ponto.

Regina Helena Costa (2003, p. 81) sugere que o legislador, sabendo da inércia processual da Fazenda Pública, decidiu antecipar-se, forçando um reexame a despeito do que o procurador desta faça no caso concreto. A autora aponta isto como um convite à inércia dos órgãos públicos:

O que se pretende é que na hipótese - a qual, infelizmente, ocorre freqüentemente no âmbito federal - de não haver recurso da parte, a sentença contrária à Fazenda Pública, de qualquer maneira, não produzirá efeitos enquanto não confirmada pelo Tribunal respectivo.

No início deste século o legislador, entendendo que a remessa necessária da Fazenda Pública estava a causar óbice à efetividade da prestação jurisdicional, editou a Lei 10.352/2001, a qual mitiga as hipóteses do reexame necessário.

O parágrafo segundo do art. 475, inserido pela Lei 10.352/2001, realizou uma limitação de conteúdo econômico financeiro nos casos de condenação das Fazendas Públicas ou de procedência de embargos à execução fiscal envolvendo quantia menor do que sessenta (60) salários mínimos. É um valor fixado de maneira randômica, todavia de grande utilidade, visto que evita discussões acerca de valores irrisórios frente ao poderio econômico-financeiro estatal, contudo contribuindo, sobremaneira, com o abarrotamento dos Tribunais. (LASPRO; APRIGLIANO, 2003, p. 242).

De igual modo, foi excluída da remessa obrigatória a sentença que se fundar em jurisprudência do plenário ou súmula do STF, bem como em súmula dos tribunais superiores competentes (STJ, TST, TSM e TSE). Desta maneira, nota-se a renovada tendência do sistema processual prestigiar cada vez mais as decisões dos tribunais 
superiores, com fito de acelerar a prestação da tutela jurisdicional (LASPRO; APRIGLIANO, 2003, p. 244).

Percebem-se diversos aspectos negativos no reexame: induz o advogado público a não recorrer, já que os autos subirão de maneira automática; leva a uma grande demora na prestação jurisdicional; mostra uma grande desconfiança do legislador com o Juiz de primeiro grau; influi numa grande desconfiança do cidadão perante os órgãos públicos e o Poder Judiciário.

Retornar-se-á à temática do reexame necessário para verificar se o mesmo configura-se como prerrogativa ou privilégio após análise acerca dos direitos fundamentais ao acesso à justiça e à razoável duração do processo.

\section{OS DIREITOS FUNDAMENTAIS AO ACESSO À JUSTIÇA E À RAZOÁVEL DURAÇÃO DO PROCESSO}

A questão da efetividade do processo tem se mostrado como de grande importância atualmente, na sociedade de consumo em massa, onde tudo acontece em instantes, destoando do resto da vida em sociedade a extensa duração dos processos judiciais, que perduram por anos sem propiciarem uma resposta jurisdicional aos cidadãos. Não só a classe jurídica, como a população leiga reclamam por uma atuação mais rápida, concreta e efetiva da jurisdição estatal.

Um dos entraves à efetividade dos processos em face dos ente públicos consiste na ininterrupta negativa, por parte dos órgãos administrativos, em prover espontaneamente os direitos dos administrados. Ademais, a constante utilização de recursos judiciais pela advocacia pública, mesmo que sejam evidentemente inviáveis é outro fator que contribui para a morosidade.

O brocardo americano já aponta: "justice delayed is not justice". Aliás, o problema na demora da jurisdição vem de longa data, como se percebe da leitura do artigo 40 da Magna Charta Libertatum: "To no one will we sell, to no one will we refuse or delay, right or justice."

Vê-se que a sociedade civil não está alheia aos problemas aqui apresentados, uma vez já tramita no Congresso Nacional um Anteprojeto com objetivo de substituir o atual CPC.

Hodiernamente, a questão do acesso à justiça é afetada pelo crescente número de demandas em curso em que é parte o Estado Brasileiro (através de seus entes federados). $\mathrm{O}$ problema do acesso à justiça ganhou nova dimensão com a Constituição Federal de 1988, que catalogou os princípios da inafastabilidade do controle jurisdicional e do devido processo legal no rol dos direitos fundamentais (LEITE, 2008, p. 68).

Ademais, o acesso à justiça, hoje também é insculpido em nossa Constituição o direito à razoável duração do processo. A citada garantia é desdobramento natural do princípio da inafastabilidade do controle jurisdicional, uma vez que a tutela a ser realizada pelo Judiciário deve ser capaz de realizar, eficazmente, aquilo que o ordenamento jurídico material reserva à parte, sendo que, só será eficaz a tutela se for prestada tempestivamente (MEDINA; WAMBIER, 2009, p. 62).

$\mathrm{O}$ direito constitucional à inafastabilidade do controle jurisdicional e da razoável duração do processo pode ser considerado corolário lógico do devido processo legal. Compreende-se que inserido na cláusula do devido processo legal existe o direito ao procedimento adequado, aderente à realidade social e consentâneo com a relação de direito material controvertida (CINTRA; GRINOVER; DINAMARCO, 2008, p. 88). 
A essência do princípio do acesso à justiça vem do direito de obter do Judiciário a tutela adequada para a pretensão, procedente ou não. Sempre que houver entraves que impeçam a entrada do interessado no Poder Judiciário, o ato normativo será inconstitucional (NERY JÚNIOR, 2004, p. 133).

Veremos, à frente, com mais detido exame, análise acerca do direito fundamental de acesso à justiça.

\subsection{ACESSO À JUSTIÇA}

Segundo Cappelletti e Garth (2002, p. 13), o estudo do direito de acesso à justiça deve ser tomado como o ponto central da moderna processualística. Neste sentido, Paroski (2006) diz:

acesso à justiça talvez seja o mais básico dos direitos fundamentais, pois que é através do seu exercício que outros direitos fundamentais podem ser assegurados quando violados, pela imposição de sua observância pelos órgãos estatais encarregados da jurisdição.

Cappelletti e Garth (2002, p. 09) apontam que o acesso à justiça, tanto no século XIX como no início do século XX, era observado com a típica visão liberal acerca dos direitos, ou seja, a visão laissez-faire, de igualdade formal. Ou seja, apesar de em teoria o acesso à justiça ser garantido a todos, só exerciam o direito aqueles com possibilidades econômicas.

Esta ideia burguesa de acesso à justiça, como as outras ideias liberais acerca dos direitos fundamentais de primeira dimensão, mostrou-se insuficiente para os anseios sociais (BORELLI; BALEOTTI, 2011). Ou seja, apenas a existência de direitos de defesa dos particulares contra o Estado não assegurava a estes uma existência sadia, vez que, apesar das Constituições preverem os direitos de primeira dimensão aos indivíduos, as mesmas não propiciavam a estes os meios para a consecução daqueles direitos (SILVA, 2003, p. 159-160).

No que se refere ao acesso à justiça no Brasil, este direito foi previsto constitucionalmente apenas na Constituição de $1946^{\mathrm{iii}}$, sendo tal garantia repetida na Constituição de $1967^{\mathrm{iv}}$, na Constituição Emendada de $1969^{\mathrm{v}}$ e na atual Constituição Federal de $1988^{\mathrm{vi}}$. Para demonstrar a evolução deste conceito, é importante afirmar que a primeira Carta Política a consolidar proteção judicial a "ameaça a direito" foi a de 1988.

Na visão de Tristão e Fachin (2009), o acesso à justiça, no âmbito constitucional brasileiro, deve ser havido como um direito fundamental e também como um princípio. Segundo o jurista alemão Robert Alexy, os princípios são mandamentos de otimização do ordenamento jurídico, normas que obrigam que algo seja realizado na maior medida possível, de acordo com as possibilidades fáticas e jurídicas. Esta lição pode parecer genérica, mas é deveras científica. Para Alexy, as condições sob as quais um princípio tem precedência em face de outro constituem o suporte fático de uma regra que expressa a consequiência jurídica do princípio que tem precedência. Ou seja, a aplicação prática do princípio ao caso concreto implica a criação de uma regra para aquele caso individual (ALEXY, 2008, p. 90-99).

Prosseguindo, verifica-se, portanto, que o acesso à justiça, da forma prevista na Constituição Brasileira, trata-se de uma norma jurídica de natureza principiológica, a qual impõe ao legislador e aos intérpretes do Direito que seja garantido aos cidadãos, da melhor maneira fática e jurídica, acesso ao Poder Judiciário, seja pela redução de 
barreiras econômico-financeiras, seja por uma ampliação democrática dos atores processuais.

Tal mandamento vem ocasionando grandes mudanças no seio do direito processual. Antes de se analisar as mudanças ocasionadas pelo enfoque de acesso à justiça, é imperiosa análise acerca das barreiras existentes a este acesso, ligadas intimamente com a atuação processual da Fazenda Pública.

\subsection{OBSTÁCULOS AO ACESSO À JUSTIÇA}

\subsubsection{Morosidade processual}

Um dos problemas mais importantes na administração da Justiça atual tem ligação com o longo tempo necessário à solução dos conflitos judiciais. As consequiências desta morosidade são funestas, principalmente para as partes economicamente frágeis.

Cruz e Tucci (1997, p. 98-109), em obra monográfica sobre o tema, salientou os diversos fatores causadores da morosidade processual:

a) institucionais, como servidores e juízes desinteressados ou pouco assíduos; a criação desmedida de novas leis pelo legislador;

b) de ordem técnica e subjetiva, como a ampla recorribilidade das decisões e a falta de vocação profissional dos juristas;

c) de insuficiência material, como a falta de servidores e juízes, prédios em más condições, etc;

Por este motivo, na Convenção Européia dos Direitos Humanos, na Convenção Interamericana de Direitos Humanos e, desde 2004 na Constituição Brasileira, há previsão de que os processos judiciais deverão ser solucionados em prazo razoável. $\mathrm{O}$ que isto significa, na prática, será visto mais à frente.

\subsubsection{As Possibilidades das Partes}

As diferenças entre os litigantes, de cunho econômico ou cultural, também influenciam no resultado final do processo. A primeira diferença, conforme entendimento de Cappelletti e Garth (2002, p. 21), é de que pessoas físicas ou jurídicas com bons recursos financeiros têm vantagens de acesso à justiça em relação àquelas que não têm. Elas podem contratar melhores serviços jurídicos e podem suportar de maneira mais adequada a demora processual.

Tal afirmativa tem íntima ligação com a capacidade das partes reconhecerem um direito judicialmente exigível, sendo que em geral aqueles com melhores recursos financeiros o fazem de maneira mais apropriada. Este aspecto é muito nítido (apesar dos grandes avanços nesta área) no direito consumerista, em que muitas vezes o consumidor que assina o contrato de adesão não nota que aquele contrato não o obrigará de maneira absoluta e peremptória.

Cappelletti e Garth também apontam como um especial problema nesta área a desconfiança que a população de baixa renda tem em relação à classe jurídica, em geral, seja com os advogados ou com os juízes (2002, p. 25).

Outra disparidade a ser apontada é em relação aos litigantes eventuais e habituais. Um estudo de Galanter citado por Cappelleti e Garth aponta que os litigantes habituais possuem largas vantagens em relação aos litigantes eventuais, por diversos motivos: economia de escala; melhor relação com os decididores da demanda; melhor planejamento dos litígios em razão da larga escala, entre outros. 
Em nossa realidade isso pode ser facilmente atestado em relação aos maiores litigantes (SANTOS, 2011) de nossa Justiça: os entes federados e os grandes bancos. Os entes federados, principalmente aqueles com maior capacidade econômica (União e Estados mais desenvolvidos economicamente) possuem procuradores com alto nível de especialização, que atuam em equipes bem distribuídas geográfica e materialmente. Já os grandes bancos, nos últimos anos, passaram a centralizar suas equipes jurídicas em grandes centros de decisão (como São Paulo e Rio de Janeiro) de onde grandes escritórios de advocacia ditam as estratégias judiciais a serem seguidas, evitando teses conflituosas.

Os problemas de acesso à justiça advindos desta grande desigualdade não foram ainda enfrentados no Brasil, até por não serem de fácil solução.

\subsection{CONSTITUCIONALIZAÇÃO DO DIREITO À RAZOÁVEL DURAÇÃO DO PROCESSO COMO SOLUÇÃO PARA O PROBLEMA DA DEMORA NA PRESTAÇÃO JURISDICIONA̧L}

A Emenda Constitucional 45/2004, conhecida como a Reforma do Judiciário, introduziu em nosso ordenamento diversas mudanças, das quais são de interesse para o presente estudo a criação do Conselho Nacional de Justiça e a introdução do inciso LXXVIII no artigo $5^{\circ}$ da Carta Magna (direito fundamental à razoável duração do processo).

Seguindo o ensinamento de Robert Alexy acerca do conteúdo jurídico dos princípios e tendo em vista o que a norma do inciso LXXVIIII prescreve ${ }^{\text {vii }}$, é possível afirmar que dentro das possibilidades fáticas e jurídicas do caso concreto é garantida uma duração razoável do processo, seja judicial ou administrativo. Isso implica em diversas conclusões. A primeira é que é vedada a edição de qualquer lei ou ato normativo que aumente irrazoavelmente a provável duração processual, seja uma lei que aumente absurdamente o rol de recursos, um ato normativo de um tribunal que determine que a distribuição processual (ou recursal) deixe de ser imediata, lei que passe a vedar a realização de inventário e divórcio sem a presença de incapazes em cartórios extrajudiciais, entre outras coisas.

A segunda conclusão está ligada aos critérios que devem ser observados para aferição da razoável duração. Cintra, Grinover e Dinamarco (2008, p. 92) pontuam que a razoável duração do processo deve ser observada sob três critérios: o da complexidade do assunto; o do comportamento dos litigantes; e da atuação do órgão jurisdicional (CINTRA; GRINOVER; DINAMARCO, 2008, p. 92). Disto decorre que os processos em que não haja multiplicidade de autores e réus, com matérias puramente de direito, deverão ser solucionados mais rapidamente do que os que possuam multiplicidade de atores processuais.

A garantia constitucional da razoável duração do processo, em conjunto com a do acesso à justiça somente terão efetividade na medida em que a legislação prever mecanismos processuais capazes de propiciá-la e o Judiciário estiver apto a absorver as demandas (MEDINA; WAMBIER, 2009, p. 62).

Uma inovação legislativa muito salutar e claramente influenciada pela introdução do inciso LXXVIII na Constituição é oriunda da lei 11.419/2006, lei que tratou da informatização do processo judicial. As petições iniciais e suas autuações terão protocolo mesmo sem a atuação de cartórios judiciais. Da mesma maneira, evitando a constante presença das partes em cartório, todos os documentos que fazem parte dos autos serão digitalizados (BATISTA, 2010, p. 68). Importante ressaltar que apesar dos avanços trazidos pelo processo digital, o mesmo não é imune a críticas, uma vez que a 
classe dos advogados vem constantemente apontando falhas no sistema on-line de protocolo de petições (CABRAL, 2011; MAMEDE, 2011).

A criação do Conselho Nacional de Justiça, órgão de controle externo do Poder Judiciário, foi um dos grandes passos para a amenização da morosidade judiciária. Com estes fins, o Conselho passou a editar metas de nivelamento anuais, entre elas a meta de nivelamento 02 , a qual prescreve que os juízes estaduais, federais, os respectivos Tribunais e os Tribunais Superiores, devem, anualmente, julgar os processos ajuizados até os quatro anos anteriores à meta, enquanto os juízes trabalhistas, eleitorais e militares devem, anualmente, julgar os processos ajuizados até os três anos anteriores à meta.

O não cumprimento das metas pelos Magistrados constará de ficha funcional, prejudicando promoção funcional por merecimento dos faltosos. Tal mecanismo é extremamente salutar para uma célere prestação da Justiça, apesar de estar recebendo críticas de magistrados, os quais entendem que o cumprimento da meta vem tornando desumana a carga de trabalho (MILÍCIO, 2009).

Pensando em conjunto com o instituto do reexame necessário e com observância dos critérios elencados, parece que há uma inversão axiológica, sendo que aquele que é inerte (o Estado) tem a 'vantagem' de ter seu processo revisto, mesmo sem ter voluntariamente feito qualquer movimento.

\section{O REEXAME NECESSÁRIO À LUZ DO ACESSO À JUSTIÇA E DA RAZOÁVEL DURAÇÃO DO PROCESSO}

A controvérsia acerca de uma suposta violação ao princípio da igualdade no reexame necessário vem de longa data. Em 1951 Alfredo Buzaid escreveu obra criticando a então chamada 'apelação ex officio' (ASSIS, 2008, p. 868). Importante ressaltar que o duplo grau de jurisdição obrigatório acabou sendo incluído no texto do CPC de 1973 à revelia de Buzaid, então Ministro da Justiça e tido como 'pai' do Código (BUENO, 2008, p. 413). Em trecho do mesmo autor (BUENO, 2008, p. 312) nota-se que as prerrogativas processuais (entre elas o reexame necessário), estão sendo utilizadas mais como "[...] subterfúgios para o não-acatamento de decisões judiciais do que necessidades inerentes, decorrentes, razoáveis ou, quando menos, toleráveis à atuação da Administração Pública" (BUENO, 2008, p. 312)

Neste contexto, no presente tópico buscar-se-á responder a seguinte pergunta: o reexame necessário sobrevive aos critérios para aferição da consecução do princípio da igualdade, como propugnados por Bandeira de Mello? Sobrevive à aplicação da regra da proporcionalidade, como propugnada por Virgílio Afonso da Silva?

Bandeira de Mello (2010, p. 21-22) aponta que para uma existência legítima de discriminação legal:

Tem-se que investigar, de um lado, aquilo que é adotado como critério discriminatório; de outro lado, cumpre verificar se há justificativa racional, isto é, fundamento lógico, para, à vista do traço desigualador acolhido, atribuir o específico tratamento jurídico construído em função da desigualdade proclamada. Finalmente, impende analisar se a correlação ou fundamento racional abstratamente existente, é, in concreto, afinado com os valores prestigiados no sistema normativo constitucional. A dizer: se guarda ou não harmonia com eles.

Para a verificação da legalidade/constitucionalidade do discrímen utilizado pelo legislador é preciso que o critério consiga ultrapassar as etapas estabelecidas por Celso Antônio Bandeira de Mello. 
Em relação ao reexame, verifica-se que a adoção do critério de desigualdade justifica-se, pela ótica do legislador, pela existência da supremacia do interesse público sobre o privado e pelo grande prejuízo compartilhado pela sociedade na ocorrência de uma derrota judicial do Poder Público. Prosseguindo, existe uma clara fundamentação lógico-racional para a existência do reexame necessário. De outro lado, nota-se que, à luz do sistema normativo-constitucional, o discrímen utilizado pelo legislador não se justifica, à luz dos princípios do acesso à justiça e da razoável duração do processo, uma vez que o reexame necessário acaba por despromover mais a razoável duração do processo e o acesso à justiça do que promover a supremacia do interesse público sobre o privado.

Neste ponto, apenas para fechar o raciocínio, vale colacionar, in verbis, duas das conclusões de Bandeira de Mello (2010, p. 47-48) acerca de quando ocorreriam ofensas ao princípio constitucional da igualdade:

\footnotetext{
A norma atribui tratamentos jurídicos diferentes em atenção a fator de discrímen adotado, que, entretanto, não guarda relação de pertinência lógica com a disparidade de regimes outorgados ${ }^{\text {viii }}$. [...]

A norma supõe relação de pertinência lógica existente em abstrato, mas o discrímen estabelecido conduz a efeitos contrapostos ou de qualquer modo dissonantes dos interesses prestigiados constitucionalmente. ${ }^{\text {ix }}$
}

Ou seja, o reexame necessário, analisado à luz da teoria de Bandeira de Mello, mostra-se como instituto anacrônico e promotor de uma desigualdade não amparada pelo Direito, motivo pelo qual deve ser visualizado como ilegal e inconstitucional.

Outro viés a ser utilizado na análise da legalidade/constitucionalidade do reexame é uma apreciação da proporcionalidade do mesmo. Conforme trabalho de Virgílio Afonso da Silva (2002) percebe-se que a proporcionalidade não é um princípio, e sim uma regra para aplicação dos princípios.

A proporcionalidade (na forma como proposta por Robert Alexy e explicada por Virgílio Afonso da Silva) surge vinculada à ideia de limitação do poder estatal. O dever de adoção da proporcionalidade está intrinsecamente ligado à concepção de moderação, prudência, equidade, vedação do excesso, dentre outras. Apesar da proporcionalidade não estar expressamente prevista em nossa Constituição, a mesma está implícita e decorre do próprio Estado de Direito (BORELLI; BALEOTTI, 2011).

A proporcionalidade atua como uma regra de interpretação e aplicação do direito, principalmente de interpretação e aplicação dos direitos fundamentais, empregada especialmente nos casos em que um ato do poder público estatal, destinado a promover a realização de um direito fundamental ou de um interesse coletivo, implica a restrição de outro direito fundamental (SILVA, 2002).

A utilidade da regra da proporcionalidade está em fazer com que nenhuma restrição a direitos fundamentais tome dimensões desproporcionais, desarrazoadas. É, para usar uma expressão consagrada, uma restrição às restrições. Para alcançar esse objetivo, o ato estatal deve passar pelos exames da adequação, da necessidade e da proporcionalidade em sentido estrito. Esses três exames são, por isso, considerados como sub-regras da regra da proporcionalidade (SILVA, 2002).

Para que seja adequado, o objetivo legítimo pretendido deve ser alcançado ou pelo menos fomentado (SILVA, 2002). Já o exame da necessidade passa pela análise da possibilidade de realização do objetivo perseguido com a mesma intensidade por meio de outro ato que limite, em menor medida, o direito fundamental atingido. Ou seja, o exame da necessidade é um exame comparativo, ou seja, analisa-se a possibilidade de outra medida ter o mesmo efeito da analisada (SILVA, 2002). 
A proporcionalidade em sentido estrito é o terceiro exame dentro do princípio da proporcionalidade, que concerne em um sopesamento entre a intensidade da restrição ao direito fundamental atingido e a importância da realização do direito fundamental que com ele colide e que fundamenta a adoção da medida restritiva.

Gustavo Binembojm (2007) resume este diagnóstico da seguinte maneira:

(I) compressão do princípio da isonomia, isto é, a discriminação criada em desfavor dos particulares seja apta a viabilizar o cumprimento pelo Estado dos fins que lhe foram cometidos pela Constituição ou pela lei [exame da adequação];

(II) o grau ou medida da compressão da isonomia, isto é, a extensão da discriminação criada em desfavor dos particulares deve observar o limite do estritamente necessário e exigível para viabilizar o cumprimento pelo Estado dos fins que lhe foram cometidos pela Constituição ou pela lei [exame da necessidade];

(III) por fim, o grau ou medida do sacrifício imposto à isonomia deve ser compensado pela importância da utilidade gerada, numa análise prognóstica de custos para os particulares e benefícios para a coletividade como um todo [exame da proporcionalidade em sentido estrito].

No primeiro momento deve ser verificado se o reexame necessário fomenta ou alcança o objetivo pretendido. O objetivo do reexame é propiciar ao Estado, automaticamente, um duplo grau de jurisdição obrigatório, no que se mostra perfeitamente adequado.

A segunda análise (da necessidade) passa por uma análise comparativa, ou seja, existiria outra medida apta a viabilizar o objetivo pretendido? Nesta senda, ao que parece, o reexame mostra-se desnecessário. Uma imposição legislativa de reexame pelo segundo grau mostra-se inócua. Isso por diversos motivos. O próprio Estado, por ato administrativo (portaria, instrução normativa, ordem de serviço), pode determinar a seus procuradores o dever de recorrer em determinados casos, sob pena de falta administrativa. Inclusive, a Lei 8.112/90, em seu artigo 117, XV já dispõe que ao servidor é proibido agir de forma desidiosa, infração esta passível inclusive de demissão do serviço público (artigo 132, XIII do mesmo diploma). Neste sentido, muito mais lógico seria que o próprio ente político regule as matérias as quais seus servidores devem recorrer, não deixando à lei tal regulação. Além disso, a edição dos atos administrativos-normativos necessita de menores formalidades em relação à edição de leis, razão pela qual podem adaptar-se mais rapidamente às mudanças circunstanciais da vida em sociedade

Outra saída também é a preconizada pelo Anteprojeto do Código de Processo Civil, em trâmite no Congresso Nacional. Neste novel diploma legislativo a matéria foi assim disciplinada:

Art. 478. Está sujeita ao duplo grau de jurisdição, não produzindo efeito senão depois de confirmada pelo tribunal, a sentença:

I - proferida contra a União, os Estados, o Distrito Federal, os Municípios e as respectivas autarquias e fundações de direito público;

II - que julgar procedentes, no todo ou em parte, os embargos à execução de dívida ativa da Fazenda Pública.

$\S 1^{\circ}$ Nos casos previstos neste artigo, o juiz ordenará a remessa dos autos ao tribunal, haja ou não apelação; não o fazendo, deverá o presidente do tribunal avocá-los.

$\S 2^{\circ}$ Não se aplica o disposto neste artigo sempre que a condenação ou o direito controvertido for de valor certo não excedente a mil salários mínimos, bem como no caso de procedência dos embargos do devedor na execução de dívida ativa do mesmo valor. 
$\S 3^{\circ}$ Também não se aplica o disposto neste artigo quando a sentença estiver fundada em jurisprudência do plenário do Supremo Tribunal Federal, em súmula desse Tribunal ou de tribunal superior competente, bem como em orientação adotada em recurso representativo da controvérsia ou incidente de resolução de demandas repetitivas.

$\S 4^{\circ}$ Quando na sentença não se houver fixado valor, o reexame necessário, se for o caso, ocorrerá na fase de liquidação.

Segundo o Anteprojeto, só haveria reexame necessário nas causas de valor excedente a mil salários mínimos ${ }^{\mathrm{x}}$, ideia interessante, visto que demonstra um 'foco' jurídico nas grandes causas, nas causas que realmente deve haver um mais detido exame, por parte tanto do Judiciário, como da Fazenda Pública, vez que podem acarretar grandes danos ao Erário em caso de derrota judicial do Poder Público.

Ademais disso, mesmo que o reexame necessário superasse o teste da necessidade (e, como visto, não o superou), Willis Santiago Guerra Filho (2007, p. 227) sustenta que o reexame necessário não ultrapassaria do teste da proporcionalidade em sentido estrito, como se denota do seguinte trecho:

\begin{abstract}
Nesse prolongamento necessário e indiscriminado do curso do processo até a instância recursal, facilmente se percebe o gravame ao direito fundamental da parte em juízo à celeridade do feito, para assim ter efetivo acesso ao que lhe é devido. Não havendo um outro interesse, público ou de relevância social, que justifique a desatenção ao interesse individual ou coletivo, de que prevaleça uma decisão de primeiro grau, da qual não há fundadas razões para se recorrer, então o indivíduo de sujeito torna-se mero objeto de um processo, por despropositado, com desrespeito à sua dignidade e da "proibição de excesso" (proporcionalidade em sentido estrito)".
\end{abstract}

Neste sentido, o reexame necessário acaba prolongando de maneira indevida a lide, retirando da decisão proferida pelo juiz de primeiro grau qualquer eficácia, prejudicando sobremaneira a eficiência e efetividade dos processos cíveis.

Perfilhando nesta trilha, percebe-se que o reexame necessário, da forma como disposto atualmente, não supera o exame da proporcionalidade (na forma delimitada por Afonso da Silva) e viola o princípio da igualdade (na forma delimitada por Bandeira de Mello), motivo pelo qual não deve permanecer vigente no ordenamento jurídico pátrio.

Algumas possibilidades de mitigação dos efeitos da retirada do reexame necessário (da maneira como está positivado atualmente) do ordenamento jurídico são a regulação por meio de ato administrativo-normativo das hipóteses de obrigatoriedade recursal pelos procuradores fazendários, ou a mudança do valor mínimo para reexame de 60 (sessenta) salários mínimos para 1.000 (mil), como previsto no Anteprojeto de Código de Processo Civil.

Ou seja, da maneira como atualmente regulamentado, o reexame necessário mostra-se como negativo e inconstitucional, sendo a redação dada pelo Anteprojeto de Código de Processo Civil uma disposição legal melhor construída, coadunando com o princípio da igualdade e com a razoável duração do processo.

De outro lado, havendo inércia do Legislativo em revogar as disposições atuais sobre o reexame necessário, e/ou aprovar o Anteprojeto, é possível ao Judiciário tomar uma postura mais firme, no sentido de declarar a inconstitucionalidade do artigo 475 do Código de Processo Civil, de acordo com a fundamentação estabelecida acima.

\title{
CONSIDERAÇÕES FINAIS
}


Portanto, de todo o acima exposto, pôde-se denotar que a Fazenda Pública detém alguns tratamentos diferenciados pela lei processual.

Verificou-se, outrossim, que o acesso à justiça da forma como previsto em nossa Constituição é uma norma jurídica de natureza principiológica, a qual impõe ao legislador e aos intérpretes do Direito que seja garantido aos cidadãos, da melhor maneira fática e jurídica, acesso ao Poder Judiciário, seja pela redução de barreiras econômico-financeiras, seja por uma ampliação democrática dos atores processuais. Além disso, utilizando-se ainda do substrato alexyano, o direito fundamental à razoável duração do processo implica numa vedação a edição de qualquer lei ou ato normativo que aumente irrazoavelmente a duração processual. Não apenas isto, como a duração razoável do processo implica que nas relações jurídica-processuais em que não haja multiplicidade de autores e réus, com matérias puramente de direito, deverão ser solucionados mais rapidamente do que os que possuam multiplicidade de atores processuais e questões complexas.

Neste diapasão, um dos institutos importantes para a Fazenda Pública é o reexame necessário (remessa necessária), a obrigatoriedade do duplo grau de jurisdição em determinadas situações legais. Existem inúmeras ressalvas a serem levantadas em relação ao citado instituto, sendo que a melhor doutrina entende por achá-lo absolutamente superado e anacrônico no atual ordenamento jurídico, visto que aponta demasiada desconfiança em relação ao Juiz de primeiro grau e entrega aos advogados públicos a chance de mesmo sem efetivamente recorrerem, adiarem o trânsito em julgado da decisão, fazendo da litigância contra o Estado um verdadeiro martírio.

Neste estudo verificou-se que, seguindo a teoria de Bandeira de Mello acerca da introdução de critérios legítimos de desigualdade pela lei, o reexame necessário, na ótica do legislador, justificar-se-ia pela existência da supremacia do interesse público sobre o privado e pelo grande prejuízo compartilhado pela sociedade na ocorrência de uma derrota judicial do Poder Público. Contudo, à luz dos princípios constitucionais do acesso à justiça e da razoável duração do processo, o discrímen utilizado pelo legislador não se justifica já que acaba por deixar mais lento o acesso à ordem jurídica justa e limita o acesso da parte à tutela do bem da vida pleiteado.

$\mathrm{Na}$ mesma linha, notou-se, utilizando-se da regra da proporcionalidade como explicada por Virgílio Afonso da Silva, que o reexame necessário não supera o exame da segunda e terceira sub-regras da proporcionalidade (necessidade e proporcionalidade em sentido estrito).

O reexame não consegue superar a análise da necessidade porque existem outras medidas que violam de maneira menos intensa direitos fundamentais e que trazem o mesmo benefício, a saber: o regramento contido no Anteprojeto de Código de Processo Civil (aumento do limite monetário mínimo para reexame de sessenta para mil salários mínimos) ou a edição de atos normativos internos pela Fazenda Pública

Além disso, é forçoso reconhecer que o reexame também não supera a análise da proporcionalidade em sentido estrito, visto que traz um indiscriminado e irrazoável prosseguimento do processo (inclusive em detrimento do entendimento do procurador fazendário), não havendo interesse público no adiamento de uma decisão com a qual o próprio Estado concorde com a 'vitória' do particular.

Ou seja, diante de toda a evolução constitucional e processual, pode-se dizer que o instituto do reexame necessário já seguiu seu curso e o melhor entendimento é que este deverá ser retirado do ordenamento jurídico brasileiro, ou declarado inconstitucional pelos órgãos do Poder Judiciário. 


\section{REFERÊNCIAS}

ALEXY, Robert. Teoria dos direitos fundamentais. São Paulo: Malheiros, 2008.

ASSIS, Araken de. Manual dos Recursos. 2.ed. São Paulo: Revista dos Tribunais, 2008.

BATISTA, Keila Rodrigues. Acesso à justiça: instrumentos viabilizadores. São Paulo: Letras Jurídicas, 2010.

BINENBOJM, Gustavo. Da supremacia do interesse público ao dever de proporcionalidade: um novo paradigma para o Direito Administrativo. In: SARMENTO, Daniel (Org.). Interesses públicos versus interesses privados: desconstruindo o princípio da supremacia do interesse público. Rio de Janeiro: Lúmen Juris, 2007, p. 117-169.

BORELLI, Rafael de Souza; BALEOTTI, Francisco Emílio. A vinculação dos particulares a direitos fundamentais no direito comparado e no Brasil: proposta de sistematização. In: Vladmir Oliveira da Silveira. (Org.). Anais do XX Congresso Brasileiro do CONPEDI. Florianópolis: Boiteux, 2011.

BUENO, Cassio Scarpinella. Curso Sistematizado de Direito Processual Civil: Recursos. Processos e incidentes nos Tribunais. Sucedâneos recursais: técnicas de controle das decisões jurisdicionais. São Paulo: Saraiva, 2008. v. 5.

CABRAL, Themys. Processo eletrônico ainda é problema para advogados. Gazeta do Povo, 22./jul.2011. Disponível em

$<$ http://www.gazetadopovo.com.br/vidaecidadania/conteudo.phtml?tl=1\&id=1149706\& tit=Processo-eletronico-ainda-e-problema-para-advogados $>$. Acesso em 12/fev. /2011.

CÂMARA, Alexandre Freitas. Lições de Direito Processual Civil. 19.ed. Rio de Janeiro: Lumen Juris, 2008. v.1.

CAPPELLETTI, Mauro; GARTH, Bryant. Acesso à justiça. Porto Alegre: Sergio Antonio Fabris, 2002.

CINTRA, Antonio Carlos de Araújo; GRINOVER, Ada Pelegrini; DINAMARCO, Cândido Rangel. Teoria Geral do Processo. 24.ed. São Paulo: Malheiros, 2008.

COSTA, Regina Helena. As prerrogativas e o interesse da justiça. In BUENO, Cássio Scarpinella; SUNDFELD, Carlos Ari (coords). Direito Processual Público. São Paulo: Malheiros, 2003.

CRUZ E TUCCI, José Rogério. Tempo e processo. São Paulo: Revista dos Tribunais, 1997.

CUNHA, Leonardo José Carneiro. A Fazenda Pública em Juízo. São Paulo: Dialética, 2008. 
DALLARI, Dalmo de Abreu. Elementos de Teoria Geral do Estado. 25. ed. São Paulo: Saraiva, 2005.

DI PIETRO, Maria Sylvia Zanella. Direito Administrativo. 20. ed. São Paulo: Atlas, 2007.

FACHIN, Zulmar; TRISTÃO, Ivan Martins. O acesso à justiça como direito fundamental e a construção da democracia pelos meios alternativos de solução de conflitos. Scientia Juris, Londrina, v. 13, p. 47-64, nov./2009.

GUERRA FILHO, Willis Santiago. Processo constitucional e direitos fundamentais. 5. ed. São Paulo: RCS, 2007.

LASPRO, Oreste Nestor de Souza; Aprigliano. Ricardo de Carvalho. Reexame necessário e recursos. In MOREIRA, Alberto Camiña; NEVES, Daniel; LASPRO, Oreste Nestor de Souza; Aprigliano. Ricardo de Carvalho; SHIMURA, Sergio. Nova reforma processual civil comentada. 2. ed. São Paulo, Método, 2003.

LEITE, Carlos Henrique Bezerra. Curso de Direito Processual do Trabalho. 6.ed. São Paulo: LTr, 2008.

MAMEDE, Marcos Vinicius Souza. Realidade para poucos, sonho para muitos. Consultor Jurídico, 01/ago./2011. Disponível em <http://www.conjur.com.br/2011ago-01/processo-eletronico-realidade-sonho>. Acesso em 12/jan./2011.

MEDINA, José Miguel Garcia; WAMBIER, T. Arruda Alvim. Processo civil moderno: Parte Geral e Processo de Conhecimento. São Paulo: Revista dos Tribunais, 2008. v.1.

MELLO, Celso Antônio Bandeira de. Conteúdo jurídico do princípio da igualdade. 3. ed. São Paulo: Malheiros, 2010.

Curso de Direito Administrativo. 12.ed. São Paulo: Malheiros, 2004.

MILÍCIO, Gláucia. Juízes dizem que Meta 2 do CNJ virou martírio, Consultor Jurídico, 08/set./2009. Disponível em < http://www.conjur.com.br/2009-set-08/metaconselho-nacional-justica-vira-martirio-juizes>. Acesso em 15/fev./2011.

MORAES, Alexandre de. Direito Constitucional. São Paulo: Saraiva, 2006.

MORAES, José Roberto de. COSTA, Regina Helena. As prerrogativas processuais da Fazenda Pública in BUENO, Cássio Scarpinella; SUNDFELD, Carlos Ari (coords).

Direito Processual Público. São Paulo: Malheiros, 2003.

NERY JUNIOR, Nelson. Princípios do processo civil na Constituição Federal. 8. ed. São Paulo: Revista dos Tribunais Ltda., 2004.

PAROSKI, Mauro Vasni. Do direito fundamental de acesso à justiça. Scientia Juris, Londrina, v. 10, p. 225-242, 2006. 
SANTOS, Ludmila. Setor público e bancos são os maiores litigantes. Consultor jurídico. 31/mar./2011. Disponível em < http://www.conjur.com.br/2011-mar-31/setorpublico-bancario-sao-maiores-clientes-justica->. Acesso em 10/jan./2011.

SILVA, de Plácido e. Vocabulário Jurídico. 26.ed. Rio de Janeiro: Forense, 2005.

SILVA, José Afonso da. Curso de direito constitucional positivo. São Paulo: Malheiros, 2003.

SILVA, Virgílio Afonso da. O proporcional e o razoável. Revista dos Tribunais, São Paulo, ano 91, n. 798, p. 23-50, 2002.

Interpretação constitucional e sincretismo metodológico. In. SILVA, Virgílio Afonso da. (org.) Interpretação Constitucional. São Paulo: Malheiros, 2005.

THEODORO JÚNIOR, Humberto. Curso de Direito Processual Civil. 15.ed. São Paulo: Forense, 2006. v.1.

VENTURI, Elton. Suspensão de liminares e sentenças contrárias ao Poder Público. São Paulo: Revista dos Tribunais, 2005.

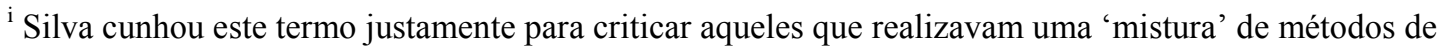
interpretação divergentes, de autores diferentes e com pensamentos absolutamente antagônicos, como se fossem compatíveis e complementares. (SILVA, 2005, passim).

${ }^{\text {ii }}$ Os outros três seriam povo, território e soberania.

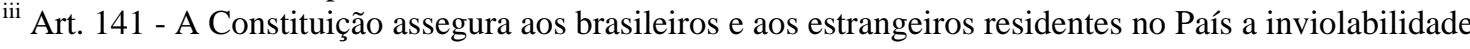
dos direitos concernentes à vida, à liberdade, a segurança individual e à propriedade, nos termos seguintes:

$\S 4^{o}$ - A lei não poderá excluir da apreciação do Poder Judiciário qualquer lesão de direito individual. (grifo nosso)

${ }^{\text {iv }}$ Art. 150 - A Constituição assegura aos brasileiros e aos estrangeiros residentes no Pais a inviolabilidade dos direitos concernentes à vida, à liberdade, à segurança e à propriedade, nos termos seguintes: $\S 4^{\circ}$ - A lei não poderá excluir da apreciação do Poder Judiciário qualquer lesão de direito individual (grifo nosso).

${ }^{v}$ Art. 153 - A Constituição assegura aos brasileiros e aos estrangeiros residentes no País a inviolabilidade dos direitos concernentes à vida, à liberdade, à segurança e à propriedade, nos têrmos seguintes: $\S 4^{\circ}$ A lei não poderá excluir da apreciação do Poder Judiciário qualquer lesão de direito individual.(grifo nosso)

${ }^{v i}$ Art. $5^{\circ}$ Todos são iguais perante a lei, sem distinção de qualquer natureza, garantindo-se aos brasileiros e aos estrangeiros residentes no País a inviolabilidade do direito à vida, à liberdade, à igualdade, à segurança e à propriedade, nos termos seguintes:

XXXV - a lei não excluirá da apreciação do Poder Judiciário lesão ou ameaça a direito;

vii LXXVIII - a todos, no âmbito judicial e administrativo, são assegurados a razoável duração do processo e os meios que garantam a celeridade de sua tramitação.

viii Aqui nota-se que a concessão do duplo grau obrigatório viola o princípio da igualdade, visto que, regra geral, o Estado acaba sendo tão bem representado judicialmente (muitas vezes melhor representado) quanto o particular, tendo em vista a existência de procuradores bem remunerados, divididos por especialidade e geograficamente, como já apontado no ensaio.

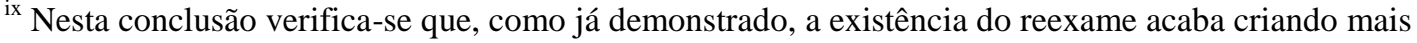
entraves a dois princípios constitucionais (acesso à justiça e razoável duração do processo) do que promovendo a igualdade substancial e a supremacia do interesse público sobre o privado.

${ }^{\mathrm{x}}$ Em valores atuais $\mathrm{R} \$ 622.000,00$
} 